\title{
ANTIOXIDANT VALUE AND ELEMENT CONTENT IN SOME TINCTURES USED IN MEDICATION
}

\author{
Klára Szentmihályi, ${ }^{1 *}$ Ilona Szöllösi Varga, ${ }^{2}$ Anita Gergely, ${ }^{3}$ \\ MÁria RÁBAI ${ }^{1}$ and MÁria THEN ${ }^{4}$ \\ ${ }^{1}$ Institute of Materials and Environmental Chemistry, Research Centre of Natural Sciences, \\ Hungarian Academy of Sciences, H-1519 Budapest, P.O. Box 286, Hungary \\ ${ }^{2}$ Department of Biochemistry and Molecular Biology, University of Szeged, Szeged, Hungary \\ ${ }^{3}$ Department of Applied Chemistry, Corvinus University of Budapest, \\ H-1118 Budapest, P.O. Box 53, Hungary \\ ${ }^{4}$ Institute of Pharmacognosy, Semmelweis University of Medicine, Budapest, Hungary
}

(Received: January 14, 2015; accepted: March 16, 2015)

\begin{abstract}
Tinctures are almost the oldest medicines and their use is substantial in the medication nowadays as well. The antioxidant values by ferric reducing/antioxidant power (FRAP) method and element content by inductively coupled plasma optical emission spectrometry (ICP-OES) were investigated in some tinctures official in the VII. and VIII. Pharmacopoeia Hungarica. The highest FRAP values were found for volatile oil containing Tinctura Aurantii amari epicarpii et mesocarpii, Tinctura Amara and Tinctura Valerianae (764.54 $\pm 19.90 ; 757.37 \pm 14.46 ; 826.40 \pm 5.89 \mu \mathrm{mol} \mathrm{l}^{-1}$, respectively). The correlations between the FRAP values and dilution with different alcohol content in Tinctura Chinae, Tinctura Ipecacuanhae normata and Tinctura Strychni were also investigated. Remarkable differences were found between the element concentrations in the different tinctures. The element contents in tinctures are not so high in absolute values nevertheless the presence of essential selenium, zinc, manganese and copper is important since they have key role in the antioxidant system. The common feature of the tinctures seems to be the lithium content. The $\mathrm{Ca}$ to $\mathrm{Mg}$ concentration ratio was found to be shifted towards magnesium in some of the tinctures that can show a higher Mg absorption which could affect against the proinflammatoric processes in the cases of gastrointestinal diseases.
\end{abstract}

Keywords: Tincture - antioxidant activity - ferric reducing/antioxidant power - elements - ICP-OES lithium

\section{INTRODUCTION}

Alcohol as a solvent is frequently used in pharmacy, perfumery and aroma industry [13]. Homeopathy also applies alcohol as a solvent for making mother tinctures to further dilution [5]. Tincture is the oldest medicine form nevertheless pharmaceutical science makes aqueous-alcoholic solutions with different alcohol content for the preferable gaining of bioactive agents. These extracts are generally prepared by maceration according to the description of Pharmacopoeia Hungaricas [20,21]. A part of tinctures is missing from the VIII. Pharmacopoeia Hungarica although their use is still substantial in the daily practice. Tinctures have more kinds of effects although the main bioactive agents are volatile oils or tannins or both.

\footnotetext{
*Corresponding author; e-mail address: szentmihalyi.klara@ttk.mta.hu
} 
The Tinctura Amara, Tinctura Aromatica, Tinctura Aurantii and Tinctura Strychni have appetizing and peptic effects. Tinctura Chinae has cholagogue and fever reducer effects, Tinctura Chamomilae and Tinctura Thymi have antiseptic and antiimflammatory effects, Tinctura Ratanhiae has astringent, Tinctura Ipecacuanhae normata and Tinctura Saponariae have expectorant effects, and Tinctura Valerianae has sedative effect $[6,12,24,27]$.

At the standardization of the tinctures some kind of features (color, odor, taste, density) and bioactive agent contents of the extracts have to be determined. There are other components in the tinctures, for example mineral elements for that there were no measurements so far. At the same time the antioxidant properties of only some tinctures have been determined so far which are commercially available and official in other pharmacopoeias $[10,16,19]$. Tinctura Chamomilae and Tinctura Valerianae used in homeopathy and alcoholic extract of thyme as a spice were also investigated nevertheless by different methods [29, 35]. Most of the tinctures investigated for antioxidant activities and published in the literature are not used for medication in Hungary and are not official in the Pharmacopoeia Hungarica, e.g. tinctures made from Ginkgo biloba, Panax ginseng, Pedilauthus titymaloides, Taxus baccata, Fagus sylvatica, Chionanthus virginicus, Baccharis incarum [1, 8, 14, 18, 22, 35].

Tinctures are able to absorb relatively fast since they can transfer directly via mucous membrane and there is no need to pass through all digestive system. Therefore active agents and elements in tincures affect relatively quickly in spite of their small amount [4]. Polyphenolic active agents, as flavonoids, tannins, have antioxidant activities [30] and their presence in the extracts, e.g. hesperidin in Tinctura Aurantii amari epicarpii et mesocarpii or tannins in Tinctura Ratanhiae, may be favourable in view of antioxidative value. Since volatile oils have relevant antioxidant activity it is supposed that the volatile oil containing tinctures also have antioxidant activities [4]. At the same time some trace elements, e.g. $\mathrm{Fe}, \mathrm{Mn}, \mathrm{Cu}$ have a key role in the biological oxidation and the antioxidant defence system as well and the presence of these elements in the tinctures can modify the antioxidant activities of the extracts [31].

Therefore some medicative tinctures available in the VII. and VIII. Pharmacopoeia Hungarica were investigated for their antioxidant value by ferric reducing/antioxidant power (FRAP) method and element content by inductively coupled plasma optical emission spectrometry (ICP-OES).

\section{MATERIALS AND METHODS}

\section{Materials}

The following tinctures official in the VII. and VIII. Pharmacopoeia Hungarica [20, 21] were examined: Tinctura Amara, Tinctura Aromatica, Tinctura Aurantii amari epicarpii et mesocarpii, Tinctura Chamomilae, Tinctura Chinae, Tinctura Ipecacuanhae normata, Tinctura Ratanhiae, Tinctura Saponariae, Tinctura Strychni, Tinctura Thymi, Tinctura Valerianae. 


\section{Preparation of tinctures by traditional method}

Tinctura Amara, Tinctura Aromatica, Tinctura Aurantii amari epicarpii et mesocarpii, Tinctura Chamomilae, Tinctura Thymi, Tinctura Chinae, Tinctura Ipecacuanhae normata, Tinctura Saponariae and Tinctura Strychni were made according to the VII. Pharmacopoeia Hungarica [20], while the preparation of Tinctura Ipecacuanhae normata, Tinctura Ratanhiae and Tinctura Valerianae was done by the description of the VIII. Pharmacopoeia Hungarica [21].

Water was used as a solvent for determination of reducing power in diluted solutions of different tinctures. The dilution rates were $2 \times, 5 \times$ and $10 \times$.

\section{Official test methods}

For controlling and measuring the bioactive agents in the tinctures the description of Pharmacopoeia Hungaricas $[20,21]$ were followed. The results were suited to the requirements.

\section{Measurements of antioxidant values}

For measurement of the ferric reducing/antioxidant power (FRAP), the following FRAP reagent solution was used according to a method modified for plant materials by Szöllősi and Szöllösi Varga: $25 \mathrm{ml}$ acetate buffer $\left(300 \mathrm{mmol} \mathrm{l}^{-1}, \mathrm{pH}=3.6 ; 3.1 \mathrm{~g}\right.$ $\mathrm{CH}_{3} \mathrm{COONa} \cdot 3 \mathrm{H}_{2} \mathrm{O}$ and $16 \mathrm{ml}$ glacial acetic acid in $1000 \mathrm{ml}$ buffer solution), $2.5 \mathrm{ml}$ TPTZ solution $\left(10 \mathrm{mmol} \mathrm{l}^{-1}\right.$ 2,4,6-tripyridyl-S-triazine in $\left.40 \mathrm{mmol} \mathrm{l}^{-1} \mathrm{HCl}\right)$ and 2.5

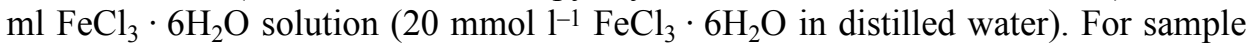
measurement $50 \mu \mathrm{l}$ sample solution was added to the $1.5 \mathrm{ml}$ FRAP reagent. The blank was a FRAP reagent. Absorbance was determined spectrometrically at $593 \mathrm{~nm}$ with $1 \mathrm{~cm}$ light path at $37^{\circ} \mathrm{C}$. Calculations were based on the calibration curve of known concentrations of $\mathrm{Fe}^{2+}$ ions using $\mathrm{FeSO}_{4} \cdot 7 \mathrm{H}_{2} \mathrm{O}[2,11,33]$.

\section{Measurement of element content by ICP-OES}

Tincture of $25 \mathrm{ml}$ was evaporated to dry then the residue was digested with $10 \mathrm{ml}$ $\mathrm{HNO}_{3}$ of $67 \%$ and $5 \mathrm{ml} \mathrm{H}_{2} \mathrm{O}_{2}$ of $30 \%$. After digestion the sample was filled to $25 \mathrm{ml}$ with bidistilled water from which concentration of elements (Al, As, B, Ba, Ca, Cd, $\mathrm{Co}, \mathrm{Cr}, \mathrm{Cu}, \mathrm{Fe}, \mathrm{Hg}, \mathrm{K}, \mathrm{Li}, \mathrm{Mg}, \mathrm{Mn}, \mathrm{Mo}, \mathrm{Na}, \mathrm{Ni}, \mathrm{P}, \mathrm{Pb}, \mathrm{S}, \mathrm{Si}, \mathrm{Sn}, \mathrm{Sr}, \mathrm{Ti}, \mathrm{V}, \mathrm{Zn}$ ) was determined with Spectro Genesis ICP-OES (ICP-OES, Kleve, Germany) equipment [29]. The concentrations of $\mathrm{As}, \mathrm{B}, \mathrm{Cd}, \mathrm{Hg}$, Ti and $\mathrm{V}$ were below the detection limits therefore these elements were omitted from the table. 


\section{Measurement of selenium by voltammetry}

Selenium content of the samples was determined with a hanging mercury drop electrode by a cathodic stripping voltammetric method (instrument: Trace Lab 50, Radiometer, Copenhagen). The digested samples $(2 \mathrm{ml})$ for ICP-OES were used in this measurement with $2 \mathrm{ml}$ bidistilled water and $2 \mathrm{ml} 1 \mathrm{M} \mathrm{HCl}$ as supporting electrolyte. The preconcentration was performed at $-350 \mathrm{mV}$. Electrolysis time: $100 \mathrm{sec}$, potential: from $-300 \mathrm{mV}$ up to $-900 \mathrm{mV}$, step duration $-50 \mathrm{mV} / \mathrm{s}$ [17].

\section{RESULTS}

\section{Antioxidant activity of tinctures}

For determination of antioxidant activity of biological systems the FRAP (ferric reducing/antioxidant power) method is frequently used therefore it has been revealed that whether this method is suitable for measurement of antioxidant activities of tinctures [9]. The FRAP values of the tinctures are summarized in Table 1. Significant differences were found between the FRAP values of different tinctures. The highest values were found for volatile oil containing Tinctura Aurantii amari epicarpii et mesocarpii, Tinctura Amara and Tinctura Valerianae although Tinctura Chamomilae and Tinctura Saponariae have also remarkable reducing ability. The volatile oil containing Tinctura Aromatica and the tannin containing Tinctura Ratanhiae are without reducing ability and Tinctura Thymi has the least FRAP value. The other tinctures showed smaller reducing ability.

Table 1

FRAP (ferric reducing/antioxidant power) values $\left(\mu \mathrm{mol} \mathrm{l}^{-1}\right)$ of tinctures

\begin{tabular}{|l|c|}
\hline \multicolumn{1}{|c|}{ Tincture } & FRAP value $\left(\mu \mathrm{mol}^{-1}\right)$ \\
\hline Tinctura Amara & $757.37 \pm 14.46$ \\
\hline Tinctura Aromatica & - \\
\hline Tinctura Aurantii amari epicarpii et mesocarpii & $764.54 \pm 19.90$ \\
\hline Tinctura Chamomilae & $654.34 \pm 10.02$ \\
\hline Tinctura Chinae & $277.82 \pm 3.93$ \\
\hline Tinctura Ipecacuanhae normata & $452.50 \pm 26.55$ \\
\hline Tinctura Ratanhiae & - \\
\hline Tinctura Saponariae & $684.75 \pm 10.02$ \\
\hline Tinctura Strychni & $470.17 \pm 11.14$ \\
\hline Tinctura Thymi & $175.76 \pm 4.28$ \\
\hline Tinctura Valerianae & $826.40 \pm 5.89$ \\
\hline
\end{tabular}




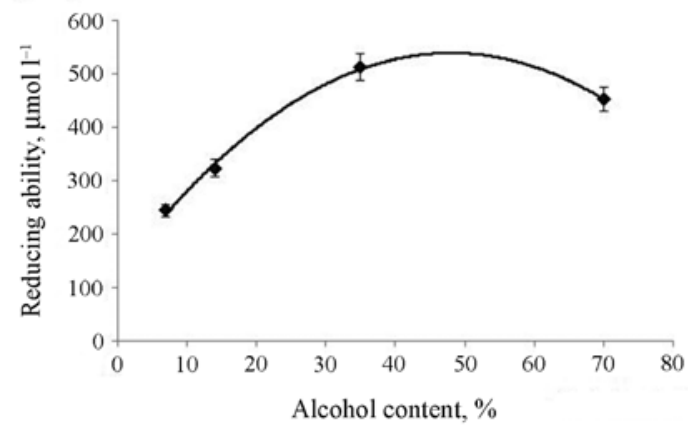

Fig. 1. Change of FRAP values $\left(\mu \mathrm{mol} \mathrm{l}^{-1}\right)$ in Tinctura Ipecacuanhae normata by dilution in the function of alcohol concentration (the dilution was made from the $70 \%$ tincture with water)

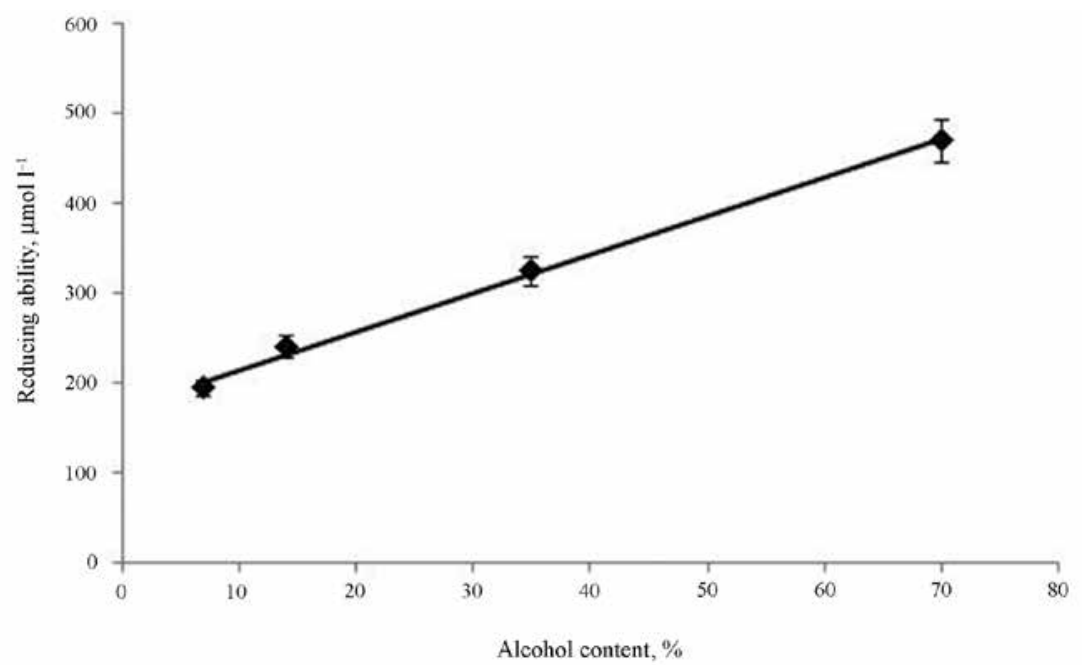

Fig. 2. Change of FRAP values $\left(\mu \mathrm{mol} 1^{-1}\right)$ in Tinctura Strychni by dilution in the function of alcohol concentration (the dilution was made from the $70 \%$ tincture with water)

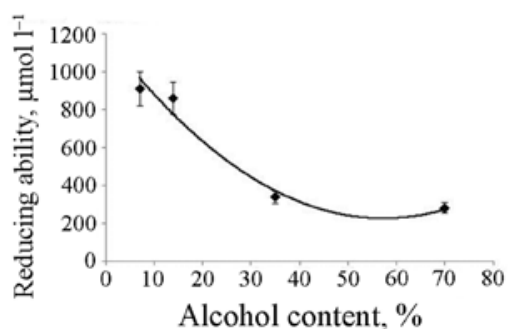

Fig. 3. Change of FRAP values $\left(\mu \mathrm{mol}^{-1}\right)$ in Tinctura Chinae by dilution in the function of alcohol concentration (the dilution was made from the $70 \%$ tincture with water) 
Table 2

Element content $\left(\mu \mathrm{g} \mathrm{ml}^{-1}\right)$ in tinctures

\begin{tabular}{|l|c|c|c|c|c|c|}
\hline & Tinctura Amara & $\begin{array}{c}\text { Tinctura } \\
\text { Aromatica }\end{array}$ & $\begin{array}{c}\text { Tinctura Aurantii } \\
\text { amari epicarpii et } \\
\text { mesocarpii }\end{array}$ & $\begin{array}{c}\text { Tinctura } \\
\text { Chamomilae }\end{array}$ & Tinctura Chinae & $\begin{array}{c}\text { Tinctura } \\
\text { Ipecacuanhae } \\
\text { normata }\end{array}$ \\
\hline \multicolumn{7}{|c|}{$\left(\mu \mathrm{g} \mathrm{ml} \mathrm{I}^{-1}\right)$} \\
\hline $\mathrm{Al}$ & $1.441 \pm 0.014$ & $1.034 \pm 0.023$ & $1.415 \pm 0.006$ & $1.053 \pm 0.13$ & $1.579 \pm 0.005$ & $0.758 \pm 0.009$ \\
\hline $\mathrm{Ba}$ & $0.266 \pm 0.002$ & $0.217 \pm 0.006$ & $0.261 \pm 0.001$ & $0.215 \pm 0.004$ & $0.376 \pm 0.002$ & $0.340 \pm 0.008$ \\
\hline $\mathrm{Ca}$ & $91.44 \pm 1.79$ & $1.275 \pm 0.159$ & $58.22 \pm 0.44$ & $17.26 \pm 1.49$ & $44.04 \pm 0.68$ & $0.606 \pm 0.077$ \\
\hline $\mathrm{Co}$ & $0.041 \pm 0.001$ & $0.036 \pm 0.001$ & $0.034 \pm 0.001$ & $0.042 \pm 0.011$ & $0.042 \pm 0.001$ & $0.035 \pm 0.001$ \\
\hline $\mathrm{Cr}$ & $0.038 \pm 0.001$ & $0.035 \pm 0.001$ & $0.049 \pm 0.001$ & $0.236 \pm 0.007$ & $<0.004$ & $<0.004$ \\
\hline $\mathrm{Cu}$ & $0.385 \pm 0.004$ & $0.117 \pm 0.001$ & $0.109 \pm 0.001$ & $0.719 \pm 0.014$ & $0.250 \pm 0.001$ & $0.041 \pm 0.001$ \\
\hline $\mathrm{Fe}$ & $0.484 \pm 0.007$ & $0.301 \pm 0.009$ & $0.995 \pm 0.002$ & $0.744 \pm 0.037$ & $1.795 \pm 0.006$ & $0.172 \pm 0.007$ \\
\hline $\mathrm{K}$ & $134.5 \pm 1.0$ & $63.88 \pm 0.34$ & $88.74 \pm 0.29$ & $148.7 \pm 13.9$ & $51.04 \pm 0.09$ & $0.738 \pm 0.028$ \\
\hline $\mathrm{Li}$ & $0.112 \pm 0.002$ & $0.061 \pm 0.002$ & $0.164 \pm 0.006$ & $0.043 \pm 0.006$ & $0.143 \pm 0.008$ & $0.026 \pm 0.001$ \\
\hline $\mathrm{Mg}$ & $38.10 \pm 0.47$ & $25.30 \pm 0.31$ & $40.55 \pm 0.01$ & $65.31 \pm 3.78$ & $41.29 \pm 0.05$ & $1.051 \pm 0.030$ \\
\hline $\mathrm{Mn}$ & $2.748 \pm 0.031$ & $0.456 \pm 0.009$ & $0.253 \pm 0.001$ & $0.171 \pm 0.005$ & $0.879 \pm 0.009$ & $0.015 \pm 0.001$ \\
\hline $\mathrm{Mo}$ & $0.007 \pm 0.005$ & $0.013 \pm 0.001$ & $0.014 \pm 0.003$ & $0.024 \pm 0.008$ & $0.033 \pm 0.008$ & $0.0058 \pm 0.0012$ \\
\hline $\mathrm{Na}$ & $25.91 \pm 0.44$ & $29.24 \pm 0.09$ & $28.44 \pm 0.14$ & $156.8 \pm 16.9$ & $17.95 \pm 0.05$ & $1.829 \pm 0.120$ \\
\hline $\mathrm{Ni}$ & $0.174 \pm 0.001$ & $0.072 \pm 0.002$ & $0.127 \pm 0.001$ & $0.318 \pm 0.010$ & $0.213 \pm 0.001$ & $0.027 \pm 0.001$ \\
\hline $\mathrm{P}$ & $32.99 \pm 0.40$ & $9.016 \pm 0.102$ & $14.85 \pm 0.09$ & $115.5 \pm 9.4$ & $9.904 \pm 0.052$ & $0.177 \pm 0.018$ \\
\hline $\mathrm{Pb}$ & $0.033 \pm 0.002$ & $0.034 \pm 0.001$ & $0.062 \pm 0.002$ & $0.045 \pm 0.002$ & $0.036 \pm 0.001$ & $0.038 \pm 0.004$ \\
\hline $\mathrm{S}$ & $1660 \pm 22$ & $645.0 \pm 15.4$ & $1087 \pm 1$ & $1457 \pm 23$ & $345.2 \pm 1.9$ & $24.89 \pm 0.46$ \\
\hline $\mathrm{Se} *$ & 0.00322 & 0.00103 & 0.00056 & $<0.0002$ & 0.00235 & $<0.0002$ \\
\hline $\mathrm{Si}$ & $5.377 \pm 0.038$ & $1.294 \pm 0.067$ & $3.862 \pm 0.280$ & $2.759 \pm 0.121$ & $3.022 \pm 0.037$ & $0.075 \pm 0.032$ \\
\hline $\mathrm{Sn}$ & $0.230 \pm 0.005$ & $0.194 \pm 0.007$ & $0.218 \pm 0.002$ & $0.156 \pm 0.002$ & $0.191 \pm 0.006$ & $0.292 \pm 0.009$ \\
\hline $\mathrm{Sr}$ & $0.171 \pm 0.021$ & $0.034 \pm 0.001$ & $0.869 \pm 0.003$ & $0.058 \pm 0.001$ & $0.166 \pm 0.001$ & $0.064 \pm 0.001$ \\
\hline $\mathrm{Zn}$ & $5.289 \pm 0.065$ & $2.806 \pm 0.053$ & $5.227 \pm 0.007$ & $1.340 \pm 0.035$ & $2.109 \pm 0.011$ & $0.104 \pm 0.005$ \\
\hline
\end{tabular}

*One measurement.

In homeopatic curing there are frequently used $98 \%$ alcoholic extracts and their dilutions were made from alkaloid containing drugs therefore we were interested in the changes of reducing power by the dilution. The reducing ability of tinctures with the dilution is very different according to tincture investigated. The result of Tinctura Ipecacuanhae normata is shown in Fig. 1. First the reducing power increased by the dilution to the double volume then decreased for further dilutions. The reducing ability of Tinctura Strychni shows a linear decrease with the dilution (Fig. 2), while in the case of Tinctura Chinae the FRAP value increased with the dilution (Fig. 3). The explanation of this very large scale difference of behavior is that the dilution of tinc- 
Table 2 (cont.)

\begin{tabular}{|c|c|c|c|c|c|}
\hline & $\begin{array}{l}\text { Tinctura } \\
\text { Ratanhiae }\end{array}$ & $\begin{array}{c}\text { Tinctura } \\
\text { Saponariae }\end{array}$ & $\begin{array}{l}\text { Tinctura } \\
\text { Strychni }\end{array}$ & $\begin{array}{l}\text { Tinctura } \\
\text { Thymi }\end{array}$ & $\begin{array}{c}\text { Tinctura } \\
\text { Valerianae }\end{array}$ \\
\hline \multicolumn{6}{|c|}{$\left(\mu \mathrm{g} \mathrm{ml}^{-1}\right)$} \\
\hline $\mathrm{Al}$ & $1.073 \pm 0.006$ & $0.716 \pm 0.025$ & $0.976 \pm 0.004$ & $1.028 \pm 0.004$ & $0.779 \pm 0.003$ \\
\hline $\mathrm{Ba}$ & $0.028 \pm 0.002$ & $0.003 \pm 0.007$ & $0.308 \pm 0.001$ & $0.416 \pm 0.001$ & $0.270 \pm 0.004$ \\
\hline $\mathrm{Ca}$ & $2.923 \pm 0.009$ & $22.15 \pm 4.40$ & $1.485 \pm 0.014$ & $786.0 \pm 11.2$ & $0.457 \pm 0.004$ \\
\hline $\mathrm{Co}$ & $0.034 \pm 0.001$ & $0.010 \pm 0.001$ & $0.045 \pm 0.001$ & $0.052 \pm 0.01$ & $0.043 \pm 0.001$ \\
\hline $\mathrm{Cr}$ & $<0.004$ & $<0.004$ & $<0.004$ & $0.031 \pm 0.001$ & $0.078 \pm 0.001$ \\
\hline $\mathrm{Cu}$ & $0.078 \pm 0.001$ & $0.351 \pm 0.023$ & $0.188 \pm 0.001$ & $0.186 \pm 0.002$ & $0.154 \pm 0.001$ \\
\hline $\mathrm{Fe}$ & $1.390 \pm 0.002$ & $1.020 \pm 0.130$ & $0.538 \pm 0.001$ & $0.200 \pm 0.002$ & $0.094 \pm 0.001$ \\
\hline $\mathrm{K}$ & $20.22 \pm 0.13$ & $781.1 \pm 12.0$ & $35.93 \pm 0.04$ & $157.1 \pm 0.9$ & $78.16 \pm 0.87$ \\
\hline $\mathrm{Li}$ & $0.048 \pm 0.003$ & $0.022 \pm 0.001$ & $5.765 \pm 0.01$ & $0.175 \pm 0.009$ & $0.128 \pm 0.029$ \\
\hline $\mathrm{Mg}$ & $9.738 \pm 0.035$ & $32.30 \pm 0.14$ & $27.41 \pm 0.15$ & $19.50 \pm 0.04$ & $30.34 \pm 0.45$ \\
\hline $\mathrm{Mn}$ & $0.015 \pm 0.001$ & $0.071 \pm 0.011$ & $2.036 \pm 0.007$ & $2.138 \pm 0.023$ & $0.144 \pm 0.008$ \\
\hline Mo & $0.049 \pm 0.001$ & $0.041 \pm 0.001$ & $0.026 \pm 0.003$ & $0.012 \pm 0.001$ & $0.071 \pm 0.006$ \\
\hline $\mathrm{Na}$ & $11.27 \pm 0.06$ & $16.76 \pm 1.75$ & $21.26 \pm 0.09$ & $28.28 \pm 0.003$ & $24.13 \pm 0.31$ \\
\hline $\mathrm{Ni}$ & $0.085 \pm 0.001$ & $0.209 \pm 0.001$ & $3.318 \pm 0.008$ & $0.320 \pm 0.005$ & $0.397 \pm 0.013$ \\
\hline $\mathrm{P}$ & $0.929 \pm 0.010$ & $90.14 \pm 12.08$ & $3.334 \pm 0.062$ & $29.31 \pm 0.35$ & $14.02 \pm 0.05$ \\
\hline $\mathrm{Pb}$ & $0.041 \pm 0.004$ & $<0.003$ & $0.037 \pm 0.002$ & $0.028 \pm 0.004$ & $0.028 \pm 0.004$ \\
\hline $\mathrm{S}$ & $148.8 \pm 0.3$ & $<1$ & $449.6 \pm 11.5$ & $4486 \pm 37$ & $438.0 \pm 11.0$ \\
\hline $\mathrm{Se}^{*}$ & $<0.0002$ & $<0.0002$ & 0.00253 & 0.00123 & 0.00044 \\
\hline $\mathrm{Si}$ & $3.685 \pm 0.168$ & $3.048 \pm 0.23$ & $1.155 \pm 0.037$ & $12.60 \pm 0.30$ & $3.53 \pm 0.06$ \\
\hline $\mathrm{Sn}$ & $0.257 \pm 0.001$ & $<0.01$ & $0.154 \pm 0.002$ & $0.172 \pm 0.008$ & $0.300 \pm 0.006$ \\
\hline $\mathrm{Sr}$ & $0.025 \pm 0.001$ & $0.014 \pm 0.004$ & $0.022 \pm 0.001$ & $0.930 \pm 0.013$ & $0.013 \pm 0.001$ \\
\hline $\mathrm{Zn}$ & $0.0279 \pm 0.001$ & $1.149 \pm 0.059$ & $6.212 \pm 0.031$ & $1.378 \pm 0.009$ & $0.666 \pm 0.007$ \\
\hline
\end{tabular}

*One measurement.

ture with water may cause hydrolysis of some compounds and precipitation of some active components and depending on the properties of these components (antioxidant or prooxidant) the antioxidant power alters.

These results involve the conclusion, that every kind of tincture may have their maximal FRAP value at different dilution unit, so the comparative results in Table 1. concern only the tinctures official in the Pharmacopoeia Hungaricas without any dilution. Each tincture should be measured by different dilutions to get to know the maximal reducing ability in aim to carry out a priority. 


\section{Element content in tinctures}

The element content in the alkaloid containing tinctures (Tinctura Chinae, Tinctura Ipecacuanhae and Tinctura Strychni) is shown in Table 2. Although the element contents are relatively low, remarkable differences can be seen between the element concentrations in the different tinctures. The highest element contents can be found in Tinctura Chinae in aspect of most elements, but $\mathrm{Li}, \mathrm{Mn}, \mathrm{Ni}, \mathrm{S}$ and $\mathrm{Zn}$ contents reach their maximal amount in Tinctura Strychni.

The element contents in volatile oil containing tinctures (Tinctura Amara, Tinctura Aromatica, Tinctura Aurantii amari epicarpii et mesocarpii, Tinctura Chamomilae, Tinctura Thymi, Tinctura Valerianae) are significantly different (Table 2). The common feature of these tinctures is that all of them contain lithium and Tinctura Thymi and Tinctura Aurantii amari epicarpii et mesocarpii were found to be the best sources of lithium. Tinctura Chamomilae contains the highest concentration of $\mathrm{Cu}, \mathrm{Mg}$ and $\mathrm{P}$. The best $\mathrm{K}$ concentration can be found in Tinctura Thymi, which is also the richest source for $\mathrm{S}$ and $\mathrm{Mn}$ beside Tinctura Amara. $\mathrm{Zn}$ is contained in an elevated amount in Tinctura Amara and Tinctura Aurantii amari epicarpii et mesocarpii.

The element content of tannin containing Tinctura Ratanhiae which is mainly externally used for painting and triterpene saponine containing Tinctura Saponariae are presented in Table 2 as well. There was not found any relevant element concentration in the tinctures. Tinctura Saponariae is by far richer in $\mathrm{Ca}, \mathrm{Mg}, \mathrm{K}$ and $\mathrm{P}$ content than Tinctura Ratanhiae. There can be multiple amounts discovered in Tinctura Saponariae.

\section{DISCUSSION}

Tinctures used in medication have significance nowadays as well. Some of them can be featured with relevant reducing ability measured by FRAP method that can be important in the development of effect and furthermore a substantial data for the valuation of tinctures [9]. The reducing ability of tinctures changed differently with the dilution according to tincture investigated. In homeopatic relation the most promising alteration was shown by Tinctura Chinae since the reducing ability increased with the dilution, while it was getting higher with bigger alcohol content in Strychni. Tinctura Ipecacuanhae normata has a maximal antioxidant power at $45-50 \%$ of alcohol content. The reducing abilities of tinctures are complex effect of antioxidant (e.g. flavonoids, tannins) and prooxidant agents (alcohol, iron and other transition metal ions) in the extracts [25, 31].

The element contents in tinctures are not so high in absolute values nevertheless the presence of essential selenium, zinc, manganese and copper is important since they have key role in the antioxidant system [26]. The $\mathrm{Ca} / \mathrm{Mg}$ concentration ratio is $5: 1$ in the blood, and it was found to be $1: 2$ in the expectorant Tinctura Ipecacuanhae normata and 1:20 in Tinctura Strychni. These shifted $\mathrm{Ca} / \mathrm{Mg}$ concentration ratios from the normal rate in blood can show a higher $\mathrm{Mg}$ absorption which could affect 
against the proinflammatory processes in the cases of gastrointestinal diseases [7, 32]. However Tinctura Chinae contains a smaller 1:1 ratio of $\mathrm{Ca}$ to $\mathrm{Mg}$ and the concentrations of these elements are significantly higher than in the other tinctures. The presence of essential elements and the favourable $\mathrm{Ca}$ to $\mathrm{Mg}$ concentration ratio in most of the alkaloid containing extracts surely contribute to the preferential action of the tinctures, mainly in the cases of the proinflammatoric processes of gastrointestinal diseases.

Lithium content is a common feature of volatile oil containing tinctures which is known as a tranquillizer [23]. The $\mathrm{Ca} / \mathrm{Mg}$ concentration ratios are generally smaller than the normal ratio in blood which can mean a favorable effect in the antiinflammatory processes. The except from this is Tinctura Thymi, which has got a surprisingly enormous amount of $\mathrm{Ca}$ and therefore a respectively high $\mathrm{Ca} / \mathrm{Mg}$ ratio.

The tannin containing expectorant Tinctura Saponariae has $2: 3 \mathrm{Ca} / \mathrm{Mg}$ concentration ratio while the ratio is $1: 3$ in the Tinctura Ratanhiae, both of them are favorable in the aspect of treatment.

The tinctures investigated, except of Tinctura Valerianae, affect through gastrointestinal system as expectorant, appetizing, cholagogue, antiseptic and antiinflammatory extract. During inflammatory process inflammatory mediators, prostaglandins $\left(\mathrm{PGD}_{2}, \mathrm{PGE}_{2}\right)$, leucotrienes and cytochines (IL-1 $\beta,-3,-6,-8,-13$, TNF- $\alpha$ ) form [3]. By prostaglandin synthesis reactive oxigen species arise that inhibit the function of cyclooxigenases (COX1, COX2). Inhibition of $\mathrm{COX} 2$ is favorable in the decreasing of inflammatory processes acting like $\mathrm{Ca}$ channel blockers as well $[3,31]$. Therefore the shifted $\mathrm{Ca} / \mathrm{Mg}$ concentration ratio from $5: 1$ to $1: 1-1: 20$ in the tinctures takes effect against the inflamed process. At the same time these altered $\mathrm{Ca} / \mathrm{Mg}$ concentration ratios inhibit the activation of PLC (phospholipase C), PKC (protein kinase C), MAPKKK (mitogen activated protein kinases) and therefore the activation of NF-kappaB (nuclear factor) as well which process acts also against the inflammation [32].

\section{REFERENCES}

1. Abreu, P., Matthew, S., González, T., Cost, D., Segundo, M. A., Fernandes, E. (2006) Antiinflammatory and antioxidant activity of a medicinal tincture from Pedilanthus tithymaloides. Life Sci. 78, 1578-1585.

2. Benzie, I. E. F., Strain, J. J. (1999) Ferric reducing/antioxidant power assay: Direct measure of the total antioxidant activity of biological fluids and modified version for simultaneous measurement of total antioxidant power and ascorbic acid concentration. Method Enzymol. 299, 15-27.

3. Blázovics, A., Lugasi, A., Hagymási, K., Szentmihályi, K., Kéry, Á. (2003) Natural antioxidants and tissue regeneration: Curative effect and reaction mechanism. In: Majumdar, D. K., Govil, J. N., Sigh, E. (eds) Phytochemistry and Pharmacology II. USA Sci. Tech. Publishing LLC, Texas, Chapter 8, pp. 107-148.

4. Chey, W. Y. (1972) Alcohol and gastric mucosa. Digestion 7, 239-251.

5. Csupor, D., Boros, K., Hohmann, J. (2013) Low potency homeopathic remedies and allopathic herbal medicines: Is there an overlap? PLOS ONE 8, Art. N. e74181. 
6. Deciga-Campos, M., Rivero-Cruz, I., Arriaga-Alba, M., Castaneda-Corral, G., Angeles-Lopez, G. E., Navarrete, A., Mata, R. (2007) Acute toxicity and mutagenetic activity of Mexican plants used in traditional medicine. J. Ethnopharm. 110, 334-342.

7. Do Amaral, A. F., Rodriguez-Junior, A. L., Filho, T. J., Vannucchi, H., Martinez, J. A. B. (2008) Effects of acute magnesium loading on pulmonary function of stable COPD patients. Med. Sci. Monit. 14, CR524-CR529.

8. Gulcin, I., Ilhaim, R., Gepdiremen, A., Boyer, L., Koksal, E. (2007) A comparative study on the antioxidant activity of fringe tree (Chionanthus virginicus L.) extracts. Afr. J. Biotechnol. 6, 410-418.

9. Hajimehdipoor, H., Gohari, A. R., Ajani, Y., Saeidnia, S. (2014) Comparative study of the total phenol content and antioxidant activity of some medicinal herbal extracts. Res. J. Pharmacogn. 1, 21-25.

10. Kowalczyk, A., Biskup, I., Fecka, I. (2012) Total phenolic content and antioxidative properties of commercial tinctures obtained from Lamiaceae plants. Nat. Prod. Commun. 7, 1631-1634.

11. Lado, C., Then, M., Varga, I., Szőke, É., Szentmihályi, K. (2004) Antioxidant property of volatile oils determined by the ferric reducing ability. Z. Naturforsch. 59c, 354-358.

12. Macedo Dearmelina, J., Pimentel Batitucci, M. C., de Oliveira Goncalves, J. L. (2012) The cytotoxic, genotoxic and mutagenic effects of Matricaria chamomilla L. tincture in vivo. Rev. Cubana Plant. Med. 17, 149-159.

13. Marques Alves, M. S., Mendes, P. C., De Pontes Vieira, J. G., Ferreira Ozela, E., Ramos Barbosa, W. L., Carrera Silva, J. O. (2010) Pharmacognostic analysis of Arrabidaea chica (Humb. \& Bonpl.) B. Verlt. leaves, Bignoniaceae. Revista Brasiileira de Farmacognosia-Brazilian J. Pharmacogn. 20, 215-221.

14. Masteiková, R., Muselík, J., Bernatoniene, J., Majiene, D., Savickas, A., Malinauskas, F., Bernatoniene, R., Peciura, R., Chalupová, Z., Dvorácková, K. (2008) Antioxidant activity of tinctures prepared from hawthorn fruits and motherwort herb. Ceska Slov. Farm. 57, 35-38.

15. Masteikova, R., Muselik, J., Bernatoniene, J., Bernatoniene, R. (2007) Antioxidative activity of Ginkgo, Echinacea, and Ginseng tinctures. Medicina-Lithuania 43, 306-309.

16. Matsiopa, I. V., Grigoreva, N. F., Meshchyshen, I. F. (2012) Effect of Echinacea tincture on the rat kidney antioxidant system under carbon tetrachloride intoxication. Pharm. Chem. J. 46, 441-442.

17. May, Z., Ladó, K., Taba, G., Csedő, K., Fekete, T., Bíró, E., Szentmihályi, K. (2005) Square wave voltammetric determination of selenium in medicinal plants. In: Galbács, Z. (ed.) Proceedings of the 12th Symposium on Analytical and Environmental Problems. Szeged, pp. 430-433.

18. Nuno, G., Zampini, I. C., Ordonez, R. M., Alberto, M. R., Arias, M. E., Isla, M. I. (2012) Antioxidant/ antibacterial activities of a topical phytopharmaceutical formulation containing a standardized extract of Baccharis incarum, an extremophil plant species from Argentina Puna. Phytother. Res. 26, 17591767.

19. Pereira, R. P., Fachinetto, R., Prestes, A. S., Wagner, C., Sudati, J. H., Boligon, A. A., Athayde, M. L., Morsch, V. M., Rocha, J. B. T. (2011) Valeriana officinalis L. ameliorates vacouus chewing movements induced by reserpine in rats. J. Neural Transmission 118, 1547-1557.

20. Pharmacopoeia Hungarica (1986) Ed. VII, Medicina Press, Budapest.

21. Pharmacopoeia Hungarica (2006) Ed. VIII, Medicina Press, Budapest.

22. Pirvu, L., Grigore, A., Bubueanu, C., Draghici, E. (2010) Comparative analytical and antioxidant activity studies on a series of Fagus sylvatica L. leaves extracts. J. Planar. Chromatogr. - Mod. TLC, 26, 237-242.

23. Rougemont, M., Ulrich, S., Hiemke, C., Corruble, E., Baumann, P. (2010) French summaries of product characteristics: content in relation to therapeutic monitoring of psychotropic drugs. Fund. Clin. Pharmacol. 24, 377-384.

24. Saric-Kundalic, B., Dobes, C., Klatte-Asselmever, V., Saukel, J. (2010) Ethnobotanical study on medicinal use of wild and cultivated plants in middle, south and west Bosnia and Herzegovina. J. Ethnopharm. 131, 33-55.

25. Shaw, S., Jayatilleke, E. (1992) The role of cellular oxidases and catalytic iron in the pathogenesis of ethanol-induced liver injury. Life Sci. 50, 2045-2052. 
26. Shenkin, A. (1995) Trace elements and inflammatory response: implications for nutritional support Nutrition 11, 100-105.

27. Stahl, E., Jahn, H. (1984) An identification test and assay for Tinctura Ratanhiae. Arch. Pharm. 317 , 573-576.

28. Szabó, M. R., Radu, D., Gavrilas, S., Chambre, D., Iditoiu, C. (2010) Antioxidant and antimicrobial properties of selected spice extracts. Int. J. Food, 13, 535-545.

29. Szentmihályi, K., Then, M. (2007) Examination of microelements in medicinal plants of the Carpathian Basin. Acta Aliment. Hung. 36, 231-236.

30. Szentmihályi, K., Gere, A., Szöllősi-Varga, I., Blázovics, A., Jasztrab, S., Ladó, K., Then, M. (2010) Inhibition of lipid peroxidation of herbal extracts (obtained from plant drug mixtures of Myrtilli folium, Phaseoli fructus sine seminibus and Salviae folium) used in type 2 diabetes mellitus. Acta Biol. Hung. 61, 45-51.

31. Szentmihályi, K., May, Z., Then, M., Hajdú, M., Böszörményi, A., Balázs, A., Lemberkovics, É., Marczal, G., Szőke, É. (2012) Metal elements, organic agents in herbal remedy, Species thymi composite, and its drug-constituents. Eur. Chem. Bull. 1, 14-21.

32. Szentmihályi, K., May, Z., Süle, K., Then, M. (2013) Mineral element content of some herbs with antiinflammatory effect used in gastrointestinal diseases. Orv. Hetil. 154, 538-543.

33. Szöllösi, R., Szöllösi Varga, I. (2002) Total antioxidant power in some species of Labiatae (Adoptation of FRAP method). Acta Biol. Szeged. 46, 125-127.

34. Vincentino, A. R. R., Mendez, F. S. (2007-2009) Antioxidant activity of plant tinctures, commonly sold in pharmacies and indicated for several types of diseases, using the DPPH methodology. Rev. Brasil. Farmacogn. 17, 384-387.

35. Vignolini, P., Gehrmann, B., Melzig, M. F., Borsacchi, L., Scardigli, A., Romani, A. (2012) Quality control and analytical test method for Taxus baccata tincture preparation. Nat. Prod. Commun. 7 , 875-877. 